\title{
The Formulation of Liquid Hand Wash Made From Coconut Shell Activated Charcoal
}

\author{
Dian Fita Lestari ${ }^{1,{ }^{*}}$ Fatimatuzzahra ${ }^{1}$ Dwi Dominica ${ }^{2}$ Risky Hadi Wibowo ${ }^{1}$ \\ ${ }^{1}$ Biology Department, Faculty of Mathematics and Natural Sciences, University of Bengkulu \\ ${ }^{2}$ Pharmacy Department, Faculty of Mathematics and Natural Sciences, University of Bengkulu \\ *Corresponding author. Email: dianfita@unib.ac.id
}

\begin{abstract}
Coconut shells are widely used as an ingredient in charcoal for cooking, daily use, and also to make activated charcoal. Activated charcoal has the ability to clean and absorb dirt on the skin, but this has not been widely used. So the purpose of this research is the use of coconut shell-activated charcoal in making liquid hand wash formulations. This research used 4 liquid hand wash formulations with activated charcoal concentrations of $1 \%, 2 \%, 3 \%$, and $4 \%$. Organoleptic test parameters were texture, color, scent, and homogeneity. The organoleptic test results showed the distinctive color of charcoal liquid hand wash, which has a distinctive scent with the addition of essential oils. The hedonic test on 25 panelists showed that the most preferred formula for activated charcoal hand wash was F2 (2\% of coconut shell activated charcoal) with rose scent.
\end{abstract}

Keywords: activated charcoal, coconut shell, liquid hand wash

\section{INTRODUCTION}

One of the things that has become a health problem in almost all places is infectious diseases, high population density, inadequate environment, low public awareness of hygiene and sanitation measures, one of which is the habit of washing hands [1]. The spread of the COVID-19 virus is also an important moment which reminds us of the importance of always washing our hands. One of the clean lifestyle habits is the habit of washing hands with antiseptic soap, which can reduce the risk of disease transmission. Hands are an organ in the human that have a critical vector for transmitting so many microorganism [2]. The cross transmission of microorganisms to others occurs when we do not wash our hands effectively. Washing hands using soap has been scientifically proven to be effective at killing bacteria and preventing the spread of infectious diseases such as diarrhea, upper respiratory tract infections and killing germs or bacteria in the hands [3]. Hand washing using soap or hand wash is also very effective at cleaning the skin of dirt and dust and significantly reduces the number of disease-causing microorganisms such as viruses, bacteria and other parasites [4]. Infection with various pathogenic germs can be found on the skin because they are the body's first defense in direct contact with the environment.

In general, almost all antiseptic hand wash on the market contain synthetic ingredients such as triclosan which have a negative effect on human skin [5]. The use of triclosan can interfere with hormones for brain growth and reproduction. Triclosan can also cause antibiotic resistance, thus inhibiting the action of drugs. In addition, it can trigger the creation of superbugs, namely bacteria that have mutated cells, thus making bacteria resistant. Frequent use of triclosan can also kill the normal flora of the skin, even though it can function as a protection for the skin. This is also supported by [6] that the use of antiseptic soap in the common for a long time can cause side effects and skin irritation. Liquid hand wash is currently widely produced because of its more practical use and more simple compared to other forms of hand wash today [7].

Activated charcoal is a carbon amorphous compound, which can be produced from materials containing carbon, one of which is the coconut shell. 
Coconut shell charcoal has a potential as a source of activated carbon because of its high carbon content up to $82.92 \%$ wt [8]. Activated carbon has also been discovered several years ago, and research has been carried out that it has the ability to remove bacteria such as Pseudomonas aeruginosa and Escherichia coli from freshwater and drinking water systems. Activated carbon which has been widely used in the cosmetic industry so far is from bamboo. Based on [9], soap produced with bamboo activated charcoal is better able to absorb dirt and dust, toxins and harmful substances from the skin, resulting in healthier skin. Based on these descriptions, it is possible that activated charcoal possessed by coconut shells can act as an adsorbent for dirt on the skin.

\section{MATERIALS AND METHODS}

\subsection{Materials}

The tools used in this research are autoclave, digital scale, small mixer (stirring rod), erlenmeyer, measuring cup, pipette, incubator, beaker glass, measuring flask, bottle, and watch glass. The materials used in the research were coconut shell activated charcoal, disodium phosphate, monosodium phosphate, sodium lauryte sulphate, propylene glycol, cocoamidea, essential oil, sodium chloride, nipagin, and aquadest.

\subsection{Hand wash formula}

Weigh all the ingredients, then put the ingredients one by one into the beaker glass while stirring. Add distilled water and stir the mixture using a small mixer/stirring rod. Stir using a mixer until a trace form (thick). Cocoamidea and propylene glycol are added to the mixture. Activated charcoal is added to the mixture and distilled water is added until it reaches $100 \mathrm{ml}$ and mix well. Add with essential oil. Pour the made soap mixture into the soap bottle container. Let it stand for about 14 days. Observe and measure the parameters for the test of liquid hand wash.

Table 1. Formulation of coconut shell activated charcoal liquid hand wash

\begin{tabular}{cccccc}
\hline Material & \multicolumn{5}{c}{ Percentage (\%) } \\
\cline { 2 - 6 } & $\begin{array}{c}\text { Formula } 0 \\
(\mathrm{~F} 0)\end{array}$ & $\begin{array}{c}\text { Formula } 1 \\
(\mathrm{~F} 1)\end{array}$ & $\begin{array}{c}\text { Formula } 2 \\
(\mathrm{~F} 2)\end{array}$ & $\begin{array}{c}\text { Formula 3 } \\
(\mathrm{F} 3)\end{array}$ & $\begin{array}{c}\text { Formula } 4 \\
(\mathrm{~F} 4)\end{array}$ \\
\hline Activated charcoal & 0 & 1 & 2 & 3 & 4 \\
\hline $\mathrm{NaCl}^{2}$ & 1,5 & 1,5 & 1,5 & 1,5 & 1,5 \\
\hline $\mathrm{Na}_{2} \mathrm{HPO}_{4}$ & 2,46 & 2,46 & 2,46 & 2,46 & 2,46 \\
\hline $\mathrm{NaH}_{2} \mathrm{PO}_{4}$ & 0,08 & 0,08 & 0,08 & 0,08 & 0,08 \\
\hline Propilenglikol & 2 & 2 & 2 & 2 & 2 \\
\hline Nipagin & 0,18 & 0,18 & 0,18 & 0,18 & 2 \\
\hline Cocoamidea & 2 & 2 & 2 & 2 & 2 \\
\hline Sodium Lauryte Sulphate & 2 & 2 & 2 & 2 & 0,25 \\
\hline Essential oil & 0,25 & 0,25 & 0,25 & 0,25 & up to 100 \\
\hline Aquadest & up to 100 & up to 100 & up to 100 & up to 100 & \\
\hline
\end{tabular}

\subsection{Organoleptic test}

The organoleptic test which is carried out is a test of liquid hand wash that has been left idle for several days, which aims to determine the appearance of liquid soap in the form of form, color, and scent which is done visually. This test needs to be done because it relates to the comfort of using hand wash.

\subsection{Panelist Hedonic Test}

The level of consumer preference for liquid hand wash was carried out through the organoleptic test. The organoleptic test conducted was the preference test (hedonic) in the form of color, texture, aroma, foam, sticky level and softness level using a Likert 1-5 scale test. The hedonic scale can be stretched or collapsed according to the desired scale range. The hedonic scale can also be converted into a numeric scale with a quality number according to the level of preference. The test scale used was $1=$ very dislike, $2=$ dislike, $3=$ neutral, $4=$ like and $5=$ very like. Panelists directly tested the hand wash products for each formula (F1, F2, F3, and F4). Assessment of sensory results is given on the questionnaire paper that has been provided by putting a checklist on the column.

\section{RESULTS AND DISCUSSION}

In the research of making liquid hand soap formula using coconut shell activated charcoal using 4 formulations with activated charcoal concentrations of $1 \%, 2 \%, 3 \%$, and $4 \%$. The organoleptic test aims to see 
the physical appearance of a preparation which includes texture, color and scent of hand wash preparations from week 0 to week 4. Based on the results of the examination on formulas F1, F2, F3 and F4 and negative control, shows no changes in shape, color and scent of hand wash preparations. Standards stipulated by Indonesian National Standard (SNI) [10] for organoleptic test for liquid hand wash, namely having a form that is liquid, having a distinctive scent and color. The form of liquid soap produced in this study is liquid, the specific scent is from the coconut shell activated charcoal and the distinctive black color of coconut shell charcoal. The results of the organoleptic examination on the negative control formula gave a white color because no coconut shell activated charcoal was added. Based on the results obtained, the results of this study meet the specifications required by SNI, namely liquid, color and have a distinctive scent (Table 2).

Based on this national standard, coconut shell activated charcoal hand wash can be fulfilled and is used for washing hands. Although hand washing is a simple and lifesaving task, but it is not always undertaken by people [11]. So, it requires a commitment to be able to maintain health of each body.

Table 2. Organoleptic test of coconut shell activated charcoal liquid hand wash

\begin{tabular}{|c|c|c|c|c|c|c|}
\hline \multirow{2}{*}{$\begin{array}{c}\text { Organoleptic } \\
\text { test }\end{array}$} & \multirow{2}{*}{$\begin{array}{c}\text { Time } \\
\text { (Week) }\end{array}$} & \multicolumn{5}{|c|}{ Formula } \\
\hline & & F0 & F1 & $\mathrm{F} 2$ & F3 & F4 \\
\hline \multirow{4}{*}{ Color } & I & White & Black & Black & Black & Black \\
\hline & II & White & Black & Black & Black & Black \\
\hline & III & White & Black & Black & Black & Black \\
\hline & IV & White & Black & Black & Black & Black \\
\hline \multirow{4}{*}{ Scent } & I & No & Specific & Specific & Specific & Specific \\
\hline & II & No & Specific & Specific & Specific & Specific \\
\hline & III & No & Specific & Specific & Specific & Specific \\
\hline & IV & No & Specific & Specific & Specific & Specific \\
\hline \multirow{4}{*}{ Form } & I & Liquid & Liquid & Liquid & Liquid & Liquid \\
\hline & II & Liquid & Liquid & Liquid & Liquid & Liquid \\
\hline & III & Liquid & Liquid & Liquid & Liquid & Liquid \\
\hline & IV & Liquid & Liquid & Liquid & Liquid & Liquid \\
\hline
\end{tabular}

The homogeneity test in this study was applied to a transparent glass object and observed the absence of separate particles. Based on the observation of the preparations, it was found that there were still formulations that were not yet homogeneous. The homogeneity test aims to ensure that all ingredients in liquid soap are completely dissolved and there are no lumps in the liquid soap. The results of the homogeneity test observations showed that the F1, F3, F4 formulas initially separated, but after the 3rd and 4th weeks were homogeneous. Based on Table 3, it can be seen that this liquid hand wash preparation is in accordance with SNI standards, namely in the form of a homogeneous liquid.

Table 3. Homogeneity test of coconut shell activated charcoal liquid hand wash

\begin{tabular}{cccccc}
\hline Time & \multicolumn{5}{c}{ Homogeneity } \\
\cline { 2 - 6 } (Week) & F0 & F1 & F2 & F3 & F4 \\
\hline I & Homogeneous & Separate & Homogeneous & Separate & Separate \\
\hline II & Homogeneous & Separate & Homogeneous & Homogeneous & Homogeneous \\
\hline III & Homogeneous & Homogeneous & Homogeneous & Homogeneous & Homogeneous \\
\hline IV & Homogeneous & Homogeneous & Homogeneous & Homogeneous & Homogeneous \\
\hline
\end{tabular}


Table 4. The Result of the Panelist Hedonic Test

\begin{tabular}{cccccc}
\hline Parameter & F0 \pm SD & F1 \pm SD & F2 \pm SD & F3 \pm SD & F4 \pm SD \\
\hline Color & $3,57 \pm 0,51$ & $3,19 \pm 0,87$ & $3,29 \pm 1,15$ & $3,38 \pm 0,97$ & $3,14 \pm 1,15$ \\
\hline Scent & $3,76 \pm 0,82$ & $3,81 \pm 0,81$ & $4,05 \pm 0,92$ & $3,19 \pm 1,08$ & $2,91 \pm 1,37$ \\
\hline Texture & $3,62 \pm 0,61$ & $3,57 \pm 1,07$ & $3,95 \pm 0,92$ & $3,57 \pm 0,81$ & $3,57 \pm 0,87$ \\
\hline Foam & $3,41 \pm 92$ & $2,91 \pm 0,88$ & $3,62 \pm 0,80$ & $3,33 \pm 1,01$ & $3,33 \pm 1,11$ \\
\hline Stickiness & $3,33 \pm 1,03$ & $3,47 \pm 0,92$ & $3,83 \pm 0,92$ & $3,81 \pm 0,98$ & $3,43 \pm 1,03$ \\
\hline Softness & $3,73 \pm 0,92$ & $3,71 \pm 0,64$ & $4,09 \pm 0,53$ & $3,47 \pm 0,87$ & $3,91 \pm 0,86$ \\
\hline
\end{tabular}

Based on the results of the hedonic test assessed by 25 panelists, it can be seen that in each formulation there are different mean values, but in general, in terms of smell, texture, foam, stickiness and softness, F2 (2\% of activated charcoal) gets an average value. The average is higher than the other formulations. For the color of liquid soap, people in general tend to feel less like black charcoal because what is widely available on the market is light-colored hand wash. For the scent of han wash, the scent of roses is preferred to the scent of lavender because lavender tends to be more pungent. This can be seen in the F4 value which shows the number is less favorable. In addition, the texture formed at F2 tends to be preferred over other formulas and is considered the least sticky, so that when rinsed there is no need for a lot of water like F4. For the level of softness, F2 was rated by the panelists as the softest among the other formulas, although almost all formulas are gentle to the hand when used. So that from the four formulas that have been tested, based on the average score of the F2 formula, the panelists like the most in terms of texture, smell, stickiness and are considered the softest to the hands compared to other formulas. So, making hand wash using coconut shell activated charcoal can be used according to national standards. It is necessary to prevent our hands from being washed using hand wash to reduce disease transmission.

\section{CONCLUSION}

Four of the coconut shells activated charcoal hand wash formulas, the most stable of which homogeneity is the organoleptic test and the hedonic test, shows that the second formula with $2 \%$ (F2) activated charcoal concentration is the best for hand wash.

\section{ACKNOWLEDGMENTS}

The author would like to thank the support of the research funding of "Penelitian Pembinaan" Faculty of Mathematics and Natural Sciences, University of
Bengkulu in 2020 with contract number 9048/UN30.12/HK/2020.

\section{REFERENCES}

[1] M.S. Isabella, A. Saputro, R.P. Vischa, H. Lutfiyati. SILAT (Cassia alata) Hand Wash sebagai Pembasmi Bakteri Staphilococcus Aureus, Jurnal Farmasi Sains dan Praktis, 5 (2019) 14-19. DOI:

https://doi.org/10.31603/pharmacy.v5i1.2072. [In Bahasa Indonesia]

[2] S.L. Edmonds-Wilson, N.I. Nurinova, C.A. Zapka, N. Fierer, M. Wilson, Review of Human Hand Microbiome Research, Journal of Dermatological Science, 80 (2015) 3-12. DOI: https://doi.org/10.1016/j.jderm sci.2015.07.006.

[3] A. Proverawati, E. Rahmawati, Perilaku Hidup Bersih dan Sehat, Nuha Medika, Yogyakarta, 2019. [In Bahasa Indonesia]

[4] F.A. Desiyanto, S.N. Djannah, Efektivitas Mencuci Tangan Menggunakan Cairan Pembersih Tangan Antiseptik (Hand Sanitizer) Terhadap Jumlah Angka Kuman, (Journal of Public Health, 7 (2013) 75-82. DOI: https://doi.org/10.12928/kesmas.v7i2.1041. [In Bahasa Indonesia]

[5] Nurhadi, S. Cicilia, Making Natural Gel Bath Soap with Active Ingredients Beyerinck Chlorella pyrenoidosa Microalgae and Lavandula latifolia Chaix Essential Oil, Essay, Ma Chung University, Poor, 2012.

[6] A. Sharma, R. Yadav, V. Gudha, U.N. Soni, J.R. Patel, Formulation and Evaluation of Herbal Hand Wash, World Journal of Pharmcay and Pharmaceutical Sciences, 5 (2016) 675-683. 
[7] A. W.Lubis, J. Maulina, Pemanfaatan Ekstrak Kulit Nanas (Ananans comosus L.) Dalam Pembuatan Hand Wash Sebagai Antibakteri, Biology Education Science \& Technology Journal, $\quad 3 \quad$ (2020) 71. DOI: https://doi.org/10.30743/best.v3i1.2438. [In Bahasa Indonesia]

[8] E. Budi, H. Nasbey, S. Budi, S. Handoko, P. Suharmanto, R. Sinansari, Sunaryo, Study of the Formation of Activated Carbon from Coconut Shell Charcoal, National Seminar on Physics, 2012.

[9] A. Dwivedi, N. Jain, P. Patel, P. Sharma, The Versatile Bamboo Charcoal, International
Conference on Multidisciplinary Research \& Practice, 2017, pp. 129-131.

[10] Badan Standar Nasional, Indonesian National Standard on Liquid Hand Soap, SNI 2588-2017, Jakarta, 2017. [In Bahasa Indonesia]

[11] O. Doronina, D. Jones, M. Martello, A. Biron, M. Lavoie-Tremblay, A Systematic Review on The Effectiveness of Interventions to Improve Hand Hygiene Compliance of Nurses in The Hospital Setting, Journal of Nursing Scholarship, 49 (2017) 143. DOI: https://doi.org/10.1111/ jnu.1227. 